\title{
REGULASI TANGGUNG JAWAB SOSIAL PERUSAHAAN DI INDONESIA
}

\author{
Erna Amalia \\ Fakultas Hukum Universitas Tama Jagakarsa Jakarta \\ E-mail: amalia.ea@gmail.com
}

\begin{abstract}
ABSTRAK
Landasan pemikiran diaturnya Tanggung Jawab Sosial Perusahaan atau Corporate Social Responsibility (CSR) bertujuan untuk mewujudkan pembangunan ekonomi berkelanjutan guna meningkatkan kualitas kehidupan dan lingkungan yang bermanfaat bagi perusahaan itu sendiri, komunitas setempat dan masyarakat pada umumnya. Pemerintah telah mengeluarkan kebijakan mengenai CSR yang terdapat pada beberapa peraturan perundang-undangan yaitu Undang-undang Nomor 40 Tahun 2007 tentang Perseroan Terbatas, Undang-undang Nomor 25 tahun 2007 tentang Penanaman Modal, Undang-undang Nomor 19 Tahun 2003 tentang Badan Usaha Milik Negara, Undang-undang Nomor 32 Tahun 2009 tentang Pengelolaan Lingkungan Hidup, Undang-undang Nomor 4 Tahun 2009 tentang Pertambangan Mineral dan Batubara. Sedangkan untuk pedoman pelaksanaannya perusahaan dapat merujuk pada ISO 26000 Guidance Standard on Social Responsibility yang menyediakan standar pedoman yang bersifat sukarela mengenai tanggung jawab sosial suatu institusi yang mencakup semua sektor, badan publik atau badan privat baik di Negara berkembang maupun Negara maju. Penelitian ini dilakukan untuk mengetahui bagaimana kebijakan pemerintah dalam mengatur tentang CSR. Penelitian yang dilakukan pada karya tulis ini adalah deskriptif analitis dengan pendekatan yang dipakai yaitu normatif yuridis yang mengacu pada peraturan perundang-undangan yang mengatur tentang CSR.
\end{abstract}

Kata kunci: Tanggung Jawab Sosial Perusahaan, Hukum Perusahaan

\section{ABSTRACT}

The regulation rationale of Corporate Social Responsibility (CSR) is to create sustainable economic development that has benefit to increase life humans' well beings, not only for the company itself, but also for its surrounding environment and people at large. The government has established a number of policies regarding CSR, such as Law Number 40 of 2007 on Limited Liability Company Law, Law Number 32 of 2007 on Investments, Law Number 19 of 2003 on StateOwned Enterprises, Law Number 4 of 2009 on Mineral and Coal Mining Law. Meanwhile, for the guidelines, we can refer to ISO 26000 Guidance Standard on Social Responsibility that providing operational guidance for CSR including private, state-owned enterprises, and government in almost every countries. This descriptive analysis research has been conducted to explore government policies concerning CSR, using juridical normative which refers to regulations of CSR.

Keywords: Corporate Social Responsibility, Corporate Law 


\section{PENDAHULUAN}

Pada hakekatnya, setiap orang, kelompok dan organisasi mempunyai tanggung jawab sosial (social responsibility) pada lingkungan sekitarnya. Tanggung jawab sosial seseorang atau organisasi adalah etika dan kemampuan berbuat baik pada lingkungan sosial berdasarkan nilai, aturan dan kebutuhan masyarakat. Perusahaan merupakan salah satu sendi kehidupan masyarakat modern, yang mana perusahaan merupakan subyek hukum selayaknya manusia (naturlijk person) yang mempunyai hak dan kewajiban.

Perusahaan (sebagai artificial person) merupakan salah satu pusat kegiatan manusia guna memenuhi kehidupannya, selain itu perusahaan juga sebagai salah satu sumber pendapatan Negara melalui pajak dan juga sebagai wadah tenaga kerja. Dalam konteks tanggung jawab sosial, didalam perusahaan dikaenal istilah tanggung jawan sosial perusahaan atau Corporate Social Responsibility (CSR), pengertian CSR sangat beragam. Banyak pihak yang berusaha merumuskan definisi CSR. Beberapa definisi CSR dibawah ini menunjukkan keragaman pengertian CSR menurut berbagai organisasi: ${ }^{1}$

1. World Business Council for Sustanable Development: komitmen berkesinambungan dari kalangan bisnis untuk perilaku etis dan memberikan kontribusi bagi pembangunan ekonomi seraya meningkatkan kualitas kehidupann karyawan dan keluarganya, serta komunitas lokal dan masyarakat luas pada umumnya.

2. International Finance Corporation: Komitmen dunia bisnis untuk memberikan kontribusi terhadap pembangunanekonomi berkelanjutan melalui kerjasama dengan karyawan, keluarga karyawan, komunitas lokal dan masyarakat luas untuk meningkatkan kehidupan mereka melalui cara yang baik bagi bisnis maupun pembangunan.

3. Institute of Chartered Accountants England and Wales: jaminan bahwa organisasi-organisasi pengelola bisnis mempu memberi dampak positif bagi masyarakat dan lingkungan, seraya memaksimalkan nilai bagi para pemegang saham (shareholders) mereka.

${ }^{1}$ Amin Widjaja Tunggal, Corporate Social Responsibility, (Jakarta, Rajawali, 2008), hal 23 
4. Canadian Government: kegiatan usaha yang menginteregasikan ekonomi, lingkungan dan sosial kedalam nilai, budaya, pengambilan keputusan, strategi dan operasi perusahaan yang dilakukan secara transparan dan bertanggung jawab untuk menciptakan masyarakat yang sehat dan berkembang.

5. European Commision: Sebuah konsep dengan nama perusahaan menginteregasikan perhatian terhadap sosial dan lingkungan dalam operasi bisnis mereka dan dalam interaksinya dengan para pemangku kepentingan (stakeholders) berdasarkan prinsip kesukarelaan.

6. CSR Asia: Komitmen perusahaan untuk beroperasi secara berkelanjutan berdasarkan prinsip ekonomi, sosial dan lingkungan seraya menyeimbangkan beragam kepentingan para stakeholders.

Versi lain mengenai definisi CSR dilontarkan oleh World Bank, Lembaga Keuangan Global ini memandang CSR sebagai "the commitment of business to contribute to sustainable economic development working with employees and then representatives the local community and society at large to improve quality of live, in ways that are both good for business and good for development." Tanggung jawab sosial dapat juga diartikan sebagai kewajiban perusahaan untuk merumuskan kebijakan, mengambil keputusan dan melaksanakan tindakan yang memberikan manfaat kepada masyarakat. ${ }^{2}$

Berdasarkan latar belakang yang telah penluis ungkapkan maka data ditarik rumusan masalah yang akan dibahas adalah bagaimanakah konsep Corporate Social Responsibility diatur dalam peraturan perundang-undangan di Indonesia?

\section{METODE PENELITIAN}

Penelitian yang lakukan pada karya tulis ini adalah penelitian hukum yuridis normatif. Dengan melakukan pendekatan perundang-undangan (Statute Approach) yang dilakukan terhadap bahan pustaka atau menggunakan data sekunder. ${ }^{3}$ Penelitian ini bersifat deskriptif, dalam melakukan penelitian, sumber data yang penulis gunakan dengan menggunakan data sekunder, yang terdiri dari bahan hukum primer, berupa peraturan perundang-undangan yang terkait

2 ibid, hal 61

3 Soerjono Soekanto, Pengantar Penelitian Hukum, cet 3, (Jakarta : Universitas Indonesia, 2014), hal. 42. 
dengan penelitian antara lain yaitu: Undang-Undang No. 40 Tahun 2007 tentang Perseroan Terbatas, Undang-Undang No. 25 Tahun 2007 tentang Penanaman Modal, Undang-Undang No. 32 Tahun 2009 tentang Perlindungan Dan Pengelolaan Lingkungan Hidup, Undang-Undang No. 22 Tahun 2001 Tentang Minyak Dan Gas Bumi, Undang-undang No. 32 tahun 2004 tentang Pemerintah Daerah, Peraturan Pemerintah No. 47 Tahun 2012 tentang Tanggung Jawab Sosial Dan Lingkungan Perseroan Terbatas, Peraturan Menteri Negara Badan Usaha Milik Negara No. PER-05/MBU/2007 Tahun 2007 Tentang Program Kemitraan Badan Usaha Milik Negara Dengan Usaha Kecil, bahan hukum sekunder berupa semua publikasi tentang hukum yang meliputi buku-buku teks, kamus-kamus hukum, jurnal-jurnal hukum; dan bahan hukum tersier berupa bahan yang memberikan petunjuk maupun penjelasan terhadap bahan hukum primer dan bahan hukum sekunder. Dalam hal ini, yang digunakan oleh penulis adalah berupa kamus dan berbagai sumber dari situs internet.

\section{PEMBAHASAN}

CSR secara umum dimaknai sebagai sebuah cara dalam rangka perusahaan mencapai sebuah keseimbangan antara tujuan-tujuan ekonomi, lingkungan dan sosial masyarakat, namun tetap merespon harapan-harapan para pemegang saham (shareholders) dan pemangku kepentingan (stakeholder). Menurut Brodshaw dan Vogel, ada tiga dimensi yang harus diperhatikan dalam kajian ruang lingkup CSR, yaitu: ${ }^{4}$

1. Corporate philantrophy adalah usaha-usaha amal yang dilakukan oleh suatu perusahaan, di mana usaha-usaha amal ini tidak berhubungan secara langsung dengen kegiatan normal perusahaan. Usaha amal dimaksud berupa pembentukan suatu badan tertentu, seperti yayasan untuk mengelola usaha amal tersebut.

2. Corporate responsibility adalah usaha sebagai wujud tanggung jawab sosial perusahaan ketika sedang mengejar profitabilitas sebagai tujuan perusahaan.

\footnotetext{
${ }^{4}$ Hendrik Budi, Corporate Social Responsibility,(Jakarta, Sinar Grafika, 2008), hal: 11
} 
3. Corporate policy adalah berkaitan erat dengan bagaimana hubungan perusahaan dengan pemerintah yang berkaitan dengan posisi tawar suatu perusahaan dengan adanya berbagai kebijaksanaan pemerintah yang mempengaruhi perusahaan maupun masyarakat secara keseluruhan.

Pembatasan ruang lingkup CSR dalam praktik etika dunia usaha modern dibedakan atas 4 (empat) bagian, yaitu:

1. Keterlibatan perusahaan dalam kegiatan-kegiatan sosial yang berguna bagi kepentingan masyarakat luas. Artinya perusahaan melakukan kegiatan bisnis tidak hanya mencari keuntungan saja, melainkan ikut memikirkan kebaikan,

2. kemajuan dan kesejahteraan masyarakat, melalui kegiatan CSR yang dilaksanakannya atas konsep keadilan distributif atau keadilan ekonomi. Tujuannya mengatasi ketimpangan sosial dan ekonomi seperti diwujudkan dalam bentuk pembangunan rumah ibadah, membangun sarana dan prasarana.

3. Memenuhi aturan hukum yang berlaku, baik yang berkaitan dengan kegiatandunia usaha maupun kehidupan sosial masyarakat pada umumnya.

4. Menghormati hak dan kepentingan stakeholders atau pihak terkait yang mempunyai kepentingan langsung maupun tidak langsung atas aktivitas perusahaan.

Selain itu, terdapat empat peraturan yang mewajibkan perusahaan tertentu untuk menjalankan program tanggung jawab sosial perusahaan atau CSR dan menggunakan acuan lain sebagai referensi dalam menjalankan tanggung jawab sosialnya yaitu ISO (Organisasi Standar Internasional).

\section{INTERNATIONAL STANDARISATION ORGANIZATION (ISO)}

International Standarisation Organization (ISO) adalah suatu asosiasi global yang terdiri dari badan-badan standardisasi nasional yang beranggotakan tidak kurang dari 140 negara. ISO merupakan suatu organisasi di luar pemerintahan (Non Government Organization/NGO) yang berdiri sejak tahun 1947. Misi dari ISO adalah untuk mendukung pengembangan standardisasi dan kegiatan-kegiatan terkait lainnya dengan harapan untuk membantu perdagangan internasional, dan juga untuk membantu pengembangan kerjasama secara global di bidang ilmu pengetahuan, teknologi dan kegiatan ekonomi. Kegiatan pokok 
ISO adalah menghasilkan kesepakatan-kesepakatan internasional yang kemudian dipublikasikan sebagai standar internasional.

Pada tahun 2004, (ISO) sebagai induk organisasi internasional, berinisiatif mengundang berbagai pihak untuk membentuk tim (working group) yang merumuskan lahirnya panduan dan standarisasi untuk tanggung jawab sosial yang diberi nama ISO 26000 : Guidance Standard on Social Responsibility. Pengaturan untuk kegiatan ISO dalam tanggung jawab sosial terletak pada pemahaman umum bahwa social responsibility adalah sangat penting untuk kelanjutan suatu organisasi. CSR merupakan salah satu bagian dari social responsibility, tidak hanya perusahaan yang perlu terpanggil untuk melakukan social responsibility, tetapi semua organisasi termasuk pemerintah dan LSM. ${ }^{5}$

ISO 26000 merupakan salah satu pedoman yang dapat digunakan oleh perusahaan dalam mengimplementasikan CSR dan bukanlah merupakan suatu sertifikasi. ISO 26000 menyediakan standar pedoman yang bersifat sukarela mengenai tanggung jawab sosial suatu institusi yang mencakup semua sektor, badan publik atau badan privat baik di Negara berkembang maupun Negara maju.

Menurut ISO 26000, CSR didefinisikan sebagai tanggung jawab dari suatu organisasi untuk dampak dari keputusan dan aktifitas di masyarakat dan lingkungan melalui transparansi dan perilaku etis yang konsisten dangan perkembangan berkelanjutan dan kesejahteraan dari masyarakat, pertimbangan harapan stakeholder sesuai dengan ketentuan hukum yang bisa diterapkan dan norma-norma internasional yang konsisten dari perilaku dan terinteregasi sepanjang organisasi.

Dengan ISO 26000 akan memberikan tambahan nilai terhadap aktivitas tanggung jawab sosial yang berkembang saat ini dengan cara:

1. Mengembangkan suatu konsensus terhadap pengertian tanggung jawab sosial dan isunya;

2. Menyediakan pedoman tentang penterjemahan prinsip-prinsip menjadi kegiatankegiatan yang efektif; dan

\footnotetext{
${ }^{5}$ HAM Hardiansyah, CSR dan model sosial untuk membangun sinergi, kemitraan bagi upaya pengentasan kemiskinan, 2007
} 
3. Memilah praktek-praktek terbaik yang sudah berkembang dan disebarluaskan untuk kebaikan komunitas atau masyarakat internasional.

Pada draft dokumen ISO 26000 disebutkan bahwa CSR adalah etika dan tindakan terkait tanggung jawab organisasi dalam berbagai pihak dengan cara-cara yang konsisten dengan kebutuhan masyarakat. Social responsibility merupakan keperdulian dan tindakan maenejemen organisasi pada masyarakat dan lingkungan, disamping harus menanti aspek legal yang berlaku. ISO 26000 memberikan prinsip-prinsi dasar, isu-isu universal dan kerangka pikir yang menjadi landasan umum bagi penyelenggaraan social responsibility oleh setiap organisasi, tanpa membedakan ukuran dan jenis organisasi. ISO 26000 tidak dimaksudkan untuk menjadi standar sistem manajeman dan tidak untuk sertifikasi perusahaan. ISO 26000 juga tidak dimaksudkan untuk menggantikan konsensus internasional yang sudah ada, tetapi untuk melengkapi dan memperkuat berbagai konsensus internasional, misalnya lingkungan, hak azasi manusia,, perlindungan pekerja, dan lain sebagianya. Prinsip penyelenggaraan social responsibility antara lain terkait dengan pembangunan berkelanjutan, penentuan dan perlipatan stakeholders; komunikasi kebijakan kinerja social responsibility; penghargaan terhadap nilai-nilai universal; pengintegrasian social responsibility dalam kegiatan normal organisasi. Oleh karena itu, ada tujuh isu utama dalam perumusan ISO 26000 Guidance Standard on Social Responsibility, yaitu ${ }^{6}$ :

1. Tata Organisasi, berhubungan dengan proses pembuatan keputusan dan struktur (organizational governance).

2. Hak Azasi manusia (HAM), berhubungan dengan aspek uji tuntas (due diligence); resiko situasi HAM; menghindari keterlibatan; menyelesaikan keluhan; diskriminasi dan kelompok rentan; hak-hak sipil dan politik; hak ekonomi, sosial dan budaya; hak fundamental di tempat kerja.

3. Praktek ketenagakerjaan, terdiri dari pekerjaan dan hubungan pekerjaan; keadaan kerja dan perlindungan sosial; dialog sosial; kesehatan dan

\footnotetext{
${ }^{6}$ Busyra Azheri Corporate Social Responsibility, (PT. Rajawali Pers, Jakarta 2011) Hal:
} $51-52$ 
keselamatan kerja; pengembangan sumber daya manusia dan pelatihan ditempat kerja.

4. Lingkungan, terdiri dari pencegahan polusi; penggunaan sumber daya yang berkelanjutan; pemecahan masalah perubahan iklim dan penyesuaian; perlindungan dan pemulihan dari lingkungan alam.

5. Praktek berusaha yang adil, terdiri dari anti korupsi; keikutsertaan yang bertanggung jawab dalam politik; kompetisi yang adil dan sehat; mempromosikan tanggung jawab sosial dalam lingkungan; menghormati Hak Kekayaan Intelektual (HKI).

6. Isu konsumen, terdiri dari pemasaran yang jujur, informasi yang factual, tidak bias dan praktek berkontrak yang jujur, melindungi kesehatan dan keamanan konsumen; konsumsi yang berkelanjutan; pelayanan konsumen, pendukung dan penyelesaian sengketa; perlindungan data konsumen dan privasi; akses ke pelayanan penting; pendidikan dan kesadaran.

7. Keikutsertaan dan pengembangan masyarakat terdiri dari, keikutsertaan masyarakat; pendidikan dan kebudayaan; penciptaan kerja dan pengembangan keahlian; pengembangan dan akses teknologi; penciptaan kekayaan dan pendapatan; kesehatan dan investasi sosial.

Ruang lingkup yang diberikan oleh ISO 26000 bukanlah suatu kewajiban, namun menjadi pedoman dalam menentukan ruang lingkup CSR di Indonesia.

\section{PERATURAN PERUNDANG-UNDANGAN}

Keberadaan CSR di Indonesia saat ini bukan hanya berupa inisiatif kebijakan dari perusahaan melainkan telah dituangkan ke dalam beberapa peraturan perundang-undangan. Berikut ketentuan mengenai CSR: 


\section{Undang-undang Nomor 40 Tahun 2007 tentang Perseroan Terbatas}

\section{(UUPT)}

CSR merupakan ketentuan baru dalam UUPT, sebelumnya dalam undangundang Nomor 1 tahun 1995 perihal mengenai tanggung jawab sosial perusahaan ini belum diatur. Pada UUPT, CSR disebut dengan istilah Tanggung Jawab Sosial dan Lingkungan diatur dalam:

a. Pasal 1 angka 3 UUPT menjabarkan tentang definisi Tanggung Jawab Sosial dan Lingkungan, yang berbunyi:

"Tanggung Jawab Sosial dan Lingkungan adalah komitmen perseroan untuk berperan serta dalam pembangunan ekonomi berkelanjutan guna meningkatkan kualitas kehidupan dan lingkungan yang bermanfaat, baik bagi perseroan sendiri, komunitas setempat, maupun masyarakat pada umumnya".

b. Pasal 74 UUPT yang berbunyi:

(1) Perseroan yang menjalankan kegiatan usahanya dibidang dan/atau berkaitan dengan sumber daya alam wajib melaksanakan Tanggung Jawab Sosial dan Lingkungan

(2) Tanggung Jawab Sosial dan Lingkungan sebagaimana dimaksud pada ayat (1) merupakan kewajiban Perseroan yang dianggarkan dan diperhitungkan sebagai biaya Perseroan yang pelaksanaannya dilakukan dengan memperhatikan kepatutan dan kewajaran.

(3) Perseroan yang tidak melaksanakan kewajiban sebagaimana dimaksud pada ayat (1) dikenai sanksi sesuai dengan ketentuan peraturan perundang-undangan.

(4) Ketentuan lebih lanjut mengenai Tanggung Jawab Sosial dan Lingkungan diatur dengan peraturan pemerintah.

Landasan pemikiran diaturnya Tanggung Jawab Sosial dan

Lingkungan dalam UUPT bertujuan untuk mewujudkan pembangunan ekonomi berkelanjutan guna meningkatkan kualitas kehidupan dan lingkungan yang bermanfaat bagi perseroan itu sendiri, komunitas setempat dan masyarakat pada umumnya. Ketentuan ini dimaksudkan untuk mendukung terjalinnya hubungan perseroan yang serasi, seimbang dan sesuai dengan lingkungan, nilai, norma dan budaya masyarakat setempat, maka ditentukan bahwa perseroan yang kegiatan usahanya dibidang dan/atau berkaitan dengan sumber daya alam wajib melaksanakan Tanggung Jawab Sosial dan Lingkungan. 
Yang dimaksud dengan "perseroan yang menjalankan kegiatan usahanya di bidang sumber daya alam" adalah perseroan yang kegiatan usahanya mengelola dan memanfaatkan sumber daya alam. Sedangkan yang dimaksud dengan "perseroan yang menjalankan kegiatan usahanya yang berkaitan dengan sumber daya alam" adalah perseroan yang tidak mengelola dan tidak memanfaatkan sumber daya alam, tetapi kegiatan usahanya berdampak pada fungsi kemampuan sumber daya alam

Dengan adanya kewajiban tersebut maka pelaksanaan CSR atau Tanggung Jawab Sosial dan Lingkungan ini dianggarkan dan diperhitungkan sebagai biaya perseroan yang pelaksanaannya dilakukan dengan adanya itukad baik serta memperhatikan kepatutan dan kewajaran. Perseroan yang tidak melaksanakan kewajiban tanggung jawab sosial dan lingkungan dikenai sanksi sesuai dengan ketentuan peraturan perundang-undangan yang terkait.

Ketentuan mengenai Tanggung Jawab Sosial dan Lingkungan pada UUPT kurang lengkap karena tidak memberikan sanksi bagi perusahaan yang tidak bersedia mematuhi kewajiban Tanggung Jawab Sosial dan Lingkungan. UUPT menyebutkan bahwa ketentuan lebih lanjut mengenai Tanggung Jawab Sosial dan Lingkungan diatur dengan Peraturan Pemerintah. Mengenai bentuk sanksi yang akan dikenakan terhadap perseroan yang tidak memenuhi kewajiban Tanggung Jawab Sosial dan Lingkungan akan diatur dalam Peraturan Pemerintah, sedangkan Peratuan Pemerintah yang mengatur mengenai sanksi terhadap perseroan yang tidak melaksanakanan Tanggung Jawab Sosial dan Lingkungan sampai saat ini belum dikeluarkan oleh Pemerintah.

2. Peraturan Pemerintah No. 47 Tahun 2012 tentang Tanggung Jawab Sosial Dan Lingkungan Perseroan Terbatas ("PP 47/2012") 
Dalam Pasal 4 PP 47/2012, dikatakan bahwa Tanggung Jawab Sosial dan Lingkungan dilaksanakan oleh Direksi berdasarkan rencana kerja tahunan perseroan setelah mendapat persetujuan Dewan Komisaris atau Rapat Umum Pemegang Saham ("RUPS”) sesuai dengan anggaran dasar perseroan. Rencana kerja tahunan perseroan tersebut memuat rencana kegiatan dan anggaran yang dibutuhkan untuk pelaksanaan Tanggung Jawab Sosial dan Lingkungan.Pelaksanaan Tanggung Jawab Sosial dan Lingkungan tersebut dimuat dalam laporan tahunan perseroan dan dipertanggungjawabkan kepada RUPS (Pasal 6 PP 47/2012).

3. Undang-undang Nomor 25 tahun 2007 tentang Penanaman Modal (UUPM)

Yang dimaksud dengan penanam modal adalah perseorangan atau badan usaha yang melakukan penanaman modal yang dapat berupa penanam modal dalam negeri dan penanam modal asing. ${ }^{7}$ Berkaitan dengan CSR, pada UUPM ditegaskan bahwa setiap penanam modal mempunyai kewajiban yaitu: ${ }^{8}$

a. menerapkan prinsip tata kelola perusahaan yang baik;

b. melaksanakan tanggung jawab sosial perusahaan;

c. membuat laporan tentang kegiatan penanaman modal dan menyampaikannya kepadaBadan Koordinasi Penanaman Modal;

d. menghormati tradisi budaya masyarakat sekitar lokasi kegiatan usaha penanaman modal; dan

e. mematuhi semua ketentuan peraturan perundang-undangan.

Menurut penjelasan pasal 15 huruf b UUPM Yang dimaksud dengan "tanggung jawab sosial perusahaan" adalah tanggung jawab yang melekat pada setiap perusahaan penanaman modal untuk tetap menciptakan hubungan yang serasi, seimbang, dan sesuai dengan lingkungan, nilai, norma, dan budaya masyarakat setempat.

\footnotetext{
${ }^{7}$ Republik Indonesia, Undang-undang Nomor 25 tahun 2007 tentang Penanaman Modal, pasal 1 angka 4

${ }^{8}$ Republik Indonesia, Undang-undang Nomor 25 tahun 2007 tentang Penanaman Modal, pasal 15
} 
Pada Pasal 16 UUPM juga diatur bahwa setiap penanam modal bertanggung jawab untuk menjaga kelestarian lingkungan hidup, selain itu ditegaskan lagi pada pasal 17 UUPM bahwa Penanam modal yang mengusahakan sumber daya alam yang tidak terbarukan wajib mengalokasikan dana secara bertahap untuk pemulihan lokasi yang memenuhi standar kelayakan lingkungan hidup, yang pelaksanaannya diatur sesuai dengan ketentuan peraturan perundangundangan. Hal ini juga merupakan bagian dari Tanggung Jawab Sosial dan Lingkungan.

Jika penanam modal tidak melakukan kewajibannya untuk melaksanakan Tanggung Jawab Sosial dan Lingkungan, maka penanam modal dapat dikenai sanksi adminisitatif berdasarkan Pasal 34 UUPM yang berbunyi:

(1) Badan usaha atau usaha perseorangan sebagaimana dimaksud dalam Pasal 5 yang tidak memenuhi kewajiban sebagaimana ditentukan dalam Pasal 15 dapat dikenai sanksi administratif berupa:

a. peringatan tertulis;

b. pembatasan kegiatan usaha;

c. pembekuan kegiatan usaha dan/atau fasilitas penanaman modal; atau

d. pencabutan kegiatan usaha dan/atau fasilitas penanaman modal.

(2) Sanksi administratif sebagaimana dimaksud pada ayat (1) diberikan oleh instansi atau lembaga yang berwenang sesuai dengan ketentuan peraturan perundang-undangan.

(3) Selain dikenai sanksi administratif, badan usaha atau usaha perseorangan dapat dikenai sanksi lainnya sesuai dengan ketentuan peraturan perundang-undangan.

Pada ketentuan yang terdapat dalam UUPM tersebut tampak bahwa basis CSR adalah corporate code of conduct, maka menjadi suatu kebutuhan akan rambu-rambu etika bisnis, agar terciptanya praktik bisnis yang beretika. Dengan adanya corporate code of conduct yang pada dasarnya 
memuat nilai-nilai etika bisnis sebagai dasar pelaksanaan CSR, maka terdapat suatu prinsip responsibility atau tanggung jawab.

\section{Undang-undang Nomor 19 Tahun 2003 tentang Badan Usaha Milik Negara (UU BUMN)}

BUMN adalah badan usaha yang seluruh atau sebagian besar modalnya dimiliki oleh Negara melalui penyertaan secara langsung yang berasal dari kekayaan Negara yang dipisahkan. ${ }^{9}$ Disamping perusahaan swasta dan koperasi, BUMN merupakan salah satu pelaku ekonomi dalam perekonomian nasional. Dalam perekonomian nasional ini BUMN berperan menghasilkan barang dan jasa yang diperlukan dalam rangka mewujudkan kemakmuran rakyat.peran BUMN dirasakan semakin pentingsebagai pelopor dan perintis dalam sector usaha yang belum dimiliki swasta. Disamping itu BUMN juga mempunyai peran strategis sebagai pelaksana pelayanan public, penyeimbang kekuatan swasta, dan turut membantu pengembangan usaha kecil dan koperasi. BUMN juga merupakan salah satu sumber penerimaan Negara yang signifikan dalam bentuk berbagai jenis pajak dan deviden.

BUMN dituntut untuk berfungsi sebagai alat pembangunan dan berperan sebagai institusi sosial. Peran sosial ini menggambarkan adanya public program (sasarannya adalah masyarakat) dan public interest (orientasinya pada kepentingan masyarakat. UU BUMN dikenal dua bentuk BUMN yaitu BUMN yang berbentuk perseroan terbatas yang modalnya terbagi dalam saham yang seluruhnya atau paling sedikit 51\% sahamnya dimiliki Negara yang tujuan utamannya mencari keuntungan. ${ }^{10}$ Bentuk BUMN lainnya berupa Perum yaitu BUMN yang seluruh modalnya dimiliki oleh Negara dan tidak terbagi atas saham, yang bertujuan untuk kemaanfaatan umum berupa penyediaan barang dan/atau jasa yang bermutu tinggi dan sekaligus

\footnotetext{
${ }^{9}$ Republik Indonesia, Undang-undang Nomor 19 tahun 2003 tentang Badan Usaha Milik Negara, pasal 1

10 ibid
} 
mengejar sekaligus mengejar keuntungan berdasarkan prinsip pengelolaan perusahaan.

Adanya instrument memaksa berupa kebijakan pemerintah menjadi factor pembeda antara BUMN dengan perseroan non-BUMN. Melalui instrument ini mau tidak mau BUMN harus mengimplementasikan program CSR. Keputusan Menteri Negara BUMN (Kepmen BUMN) ini pada prinsipnya mengikat BUMN untuk menyelenggarakan Program Kemitraan dan Bina Lingkungan (atau disingkat menjadi PK dan $\mathrm{BL}^{11}$. PK adalah program untuk mengingkatkan usaha kecil dalam bentuk pinjaman baik untuk modal usaha maupun pembelian perangkat penunjang produksi agar usaha kecil menjadi tangguh dan mandiri. Sementara BL adalah program pemberdayaan kondisi sosial masyarakat untuk tujuan yang memberikan manfaat kepada masyarakat di wilayah usaha BUMN yang bersangkutan. Kedua program ini bersumber pada penyisihan laba setelah pajak, sedangkan untuk pemanfaatan dan peruntukannya terdapat perbedaan diantara keduanya. PK diberikan dalam bentuk pinjaman khusus yang biasanya bersifat jangka pendek. Sedangkan BL pemberiannya lebih berdimensi sosial misalnya dalam bentuk bantuan bagi korban bencana alam, pendidikan, pelatihan, peningkatan kesehatan dan pengembangan sarana prasarana umum dan sarana ibadah.

Setiap BUMN diisyaratkan membentuk unit tersendiri yang bertugas secara khusus menangani PK dan BL ini. Unit ini menjadi bagian tidak terpisahkan dari organisasi perseroan dan bertanggungjawab langsung kepada salah satu anggota direksi yang ditetapkan.

5. Peraturan Menteri Negara Badan Usaha Milik Negara No. PER05/MBU/2007 Tahun 2007 Tentang Program Kemitraan Badan Usaha Milik Negara Dengan Usaha Kecil Dan Program Bina 
Lingkungan sebagaimana terakhir diubah dengan Peraturan Menteri Badan Usaha Milik Negara No. PER-08/MBU/2013 Tahun 2013 Tentang Perubahan Keempat Atas Peraturan Menteri Negara Badan Usaha Milik Negara No.PER-05/MBU/2007 Tentang Program Kemitraan Badan Usaha Milik Negara Dengan UsahaKecil Dan Program Bina Lingkungan ("Permen BUMN 5/2007')

Dalam peraturan ini diatur mengenai kewajiban Perusahaan Perseroan ("Persero"), Perusahaan Umum ("Perum"), dan Perusahaan Perseroan Terbuka ("Persero Terbuka").

Berdasarkan Pasal 2 Permen BUMN 5/2007, Persero dan Perum wajib melaksanakan Program Kemitraan BUMN dengan Usaha Kecil dan Program Bina Lingkungan. Sedangkan Persero Terbuka dapat melaksanakan Program Kemitraan BUMN dengan Usaha Kecil dan Program Bina Lingkungan dengan berpedoman pada Permen BUMN 5/2007 yang ditetapkan berdasarkan keputusan RUPS.

Program Kemitraan BUMN dengan Usaha Kecil adalah program untuk meningkatkan kemampuan usaha kecil agar menjadi tangguh dan mandiri melalui pemanfaatan dana BUMN (Pasal 1 angka 6 Permen BUMN 5/2007). Sedangkan Program Bina Lingkungan adalah program pemberdayaan kondisi sosial masyarakat oleh BUMN melalui pemanfaatan dana BUMN (Pasal 1 angka 7 Permen BUMN 5/2007).

\section{Undang-undang Nomor 32 tahun 2009 tentang Pengelolaan Lingkungan Hidup (UUPLH)}

Pada dasarnya manusia memiliki hak atas lingkungan hidup sebagai salah satu bagian dari hak azasi manusia. Pada dasarnya hak atas lingkungan hidup yang baik dan sehat adalah diakuinya hak lingkungan hidup untuk dilindungi dan dilestarikan, namun lingkungan hidup sebgai penyandang hak tidak dapat mempertahankan haknya 
tanpa bantuan manusia oleh karena itu diperlukan peran setiap orang bagi orang perseorangan atau kelompok dan atau badan hukum. ${ }^{12}$

Berdasarkan Pasal 68 UU 32/2009, setiap orang yang melakukan usaha dan/atau kegiatan berkewajiban:

a. memberikan informasi yang terkait dengan perlindungan dan pengelolaan lingkungan hidup secara benar, akurat, terbuka, dan tepat waktu;

b. menjaga keberlanjutan fungsi lingkungan hidup; dan

c. menaati ketentuan tentang baku mutu lingkungan hidup dan/atau kriteria baku kerusakan lingkungan hidup.

Dengan diaturnya hak atas lingkungan hidup dalam peraturan hukum nasional maka timbul dua fungsi dari pengaturan tersebut yaitu the function of defense adalah hak untuk membela diri terhadap gangguan luar yang merugikan lingkungan dan the function of performance adalah hak menuntut dilakukannya suatu tindakan agar lingkungan dapat dilestarikan, dipulihkan atau diperbaiki. ${ }^{13}$ Dari situ dapat dilihat bahwa masalah lingkungan hidup juga merupakan tanggungjawab sosial bagi korporasi sebagai legal entity untuk mempertahankan kelestariannya dan sudah selayaknya mengimplementasikan apa yang menjadi tujuan sosialnya. Salah satu wujud dari adanya tanggung jawab sosial perseroan pada lingkungan adalah dengan memenuhi persyaratan Analisis Mengenai Dampak Lingkungan (AMDAL) sebelum memulai kegiatan usaha bagi perseroan-perseroan tertentu serta melakukan produksi yang ramah lingkungan dan menghasilkan barang yang ramah lingkungan misalnya dengan memperhatikan pembuangan limbah dan dengan adanya program daur ulang limbah.

12 Hendrik Budi, Corporate Social Responsibility, Sinar Grafika, 2008 Jakarta Hal 20

${ }^{13}$ Republik Indonesia, Undang-undang No. 32 tahun 2009 tentang Pengelolaan Lingkungan Hidup, pasal 34 


\section{Undang-undang Nomor 4 Tahun 2009 tentang Pertambangan Mineral dan Batubara (UU Minerba)}

Dengan adanya otonomi daerah yang diatur dalam Undang-undang Nomor 32 tahun 2004 maka berpengaruh terhadap dunia pertambangan di Indonesia karena sesuai dengan otonomi daerah maka setiap daerah berhak atas kekayaannya masing-masing ${ }^{14}$ dalam hal ini termasuk juga tambang mineral dan batubara. Hal ini berpengaruh terhadap izin kuasa pertambangan yang harus dimiliki oleh setiap perseoan pertambangan yang melakukan penambangan di suatu daerah. Dalam Undang-undang nomor 11 tahun 1967 tentang Ketentuan-ketentuan pokok Pertambangan, penugasan bahan galian dikuasai oleh pemerintah pusat demikian juga kewenangan pengelolaannya yang bersifat nasional, oleh karena itu undang-undang ini dianggap tidak relevan setelah adanya otonomi daerah yang kemudiandigantikan oleh Undang-undang Nomor 4 tahun 2009 tentang Pertambangan Mineral dan Batubara (UU Minerba).

Dalam UU Minerba ditegaskan bahwa perseroan wajib menyelenggarakan program community development dan melakukan reklamasi pascatambang. UU Minerba mengadopsi semangat desentralisasi UU Otonomi Daerah, dengan membuat aturan perijinan dan implikasi penerimaan dana pajak dan non-pajak pemerintah pusat dan daerah. Dalam UU Minerba pengembangan wilayah dan masyarakat merupakan kewajiban bagi pemerintah daerah sekaligus merupakan keharusan bagi pemegang Izin Usaha Pertambangan (IUP) dan Izin Usaha Pertambangan Khusus (IUPK) sehingga terdapat hubungan yang saling menguntungkan antara pemegang IUP maupun IUPK dengan masyarakat daerah tambang itu sendiri.

\footnotetext{
${ }^{14}$ Republik Indonesia, Undang-undang No. 32 tahun 2004 tentang Pemerintah Daerah, pasal 1 angka 5
} 
CSR dalam UU Minerba diatur dalam pengaturan mengenai hak dan kewajiban pemegang IUP dan IUPK yaitu kewajiban untuk melaksanakan ketentuan keselamatan dan kesehatan kerja pertambangan, keselamatan operasi pertambangan, pengelolaan pemantauan lingkungan pertambangan termasuk kegiatan reklamasi dan pasca tambang, upaya konservasi mineral dan batubara, pengelolaan sisa tambang dari suatu kegiatan pertambangan dalam bentuk padat, cair atau gas sampai memenuhi standar baku mutu lingkungan sebelum dilepas ke media lingkungan. ${ }^{15}$ Maka dapat disimpulkan bahwa CSR merupakan kewajiban pelaku usaha pertambangan guna menciptakan hubungan yang saling menguntungkan bagi daerah pertambangan dan bagi pelaku usaha pertambangan.

Kegiatan usaha hulu yang dilaksanakan oleh Badan Usaha atau Bentuk Usaha Tetap berdasarkan Kontrak Kerja Sama dengan Badan Pelaksana wajib memuat ketentuan-ketentuan pokok yang salah satunya adalah ketentuan mengenai pengembangan masyarakat sekitarnya dan jaminan hak-hak masyarakat adat (Pasal 11 ayat (3) huruf $p$ UU 22/2001).

Selain itu dalam Pasal 40 ayat (5) UU 22/2001 juga dikatakan bahwa Badan Usaha atau Bentuk Usaha Tetap yang melaksanakan kegiatan usaha Minyak dan Gas Bumi (kegiatan usaha hulu dan kegiatan usaha hilir) ikut bertanggung jawab dalam mengembangkan lingkungan dan masyarakat setempat.

Banyak pengamat yang berpendapat bahwa CSR berkembang guna membendung derasnya dominasi korporasi dalam ekonomi pasar, sedangkan kemiskinan, ketimpangan, ketidakadilan serta kerusakan lingkungan semakin

\footnotetext{
15 Republik Indonesia, Undang-undang No 4 tahun 2009 tentang Pertambangan Mineral dan Batubara, Pasal 96
} 
parah. Dalam system welfare state di Eropa Barat umumnyaperan Negara sangat kuat sehingga pelaksanaan program CSR sebagian besar ditangani oleh Negara. Negara berperan aktif menciptakan keadilan dan melakukan restribusi kesejahteraan melalui system pajak dan kebijakan sosial, sehingga ruang bagi korporasi melakukan eksploitasi terhadap lingkungan fisik dan sosial secara berlebihan. System aturan untuk bisnis sudah demikian detail diatur sehingga ruang untuk melakukan eksploitasi berlebih hampir tidak mungkin, terkecuali adanya pelanggaran aturan seperti aturan perpajakan.

Pada masyarakat di Negara berkembang, Negara belum mampu menyediakan kesejahteraan serta menciptakan rasa keadilan sosial, sehingga tugas ini mengalir dan menjadi beban sektor lain. Karena keterbatasan Negara maka tugas menciptakan social justice dan meredistribusikan well being menjadi tugas sektor bisnis dan masyarakat. Karenanya konsep CSR sangat sarat beban karena diisi oleh tanggung jawab yang sebenarnya merupakan tanggung jawab Negara.

Dengan adanya beberapa peraturan mengenai tanggung jawab sosial bagi perusahaan yang berlaku saat ini, timbul beberapa masalah, yaitu:

1. Pertentangan antara kertentuan CSR pada UUPT dan UUPM. Dalam UUPM tidak membedakan kewajiban tanggung jawab sosial atau CSR pada perusahaan berdasarkan bidang usahanya, sedangkan pada UUPT yang diwajibkan untuk melaksanakan CSR adalah perusahaan yang bergerak dan/atau berkaitan dengan sumber daya alam, melihat banyaknya manfaat yang didapat oleh perusahaan dan masyarakat apabila dilaksanakannya program CSR.

2. Pengaturan sanksi dalam UUPT kurang jelas, berdasarkan pasal 74 ayat (3) UUPT menyebutkan bahwa perseroan yang tidak melaksanakan kewajiban Tanggung Jawab Sosial dan Lingkungan dikenaisanksi sesuai dengan ketentuan perundang-undangan. Namun sanksi tersebut juga tidak diperjelas dalam peraturan pelaksananya, yaitu seperti yang tercantum pada pasal 7 PP Nomor. 47 tahun 2012 yang isinya menyatakan bahwa perseroan yang tidak melaksanakan tanggung jawab sosial dan lingkungan dikenai sanksi sesuai dengan peraturan perundang-undangan. Kemudian, kurangnya enforcement dari pemerintah agar perusahaan swasta mengimplementasikan tanggung 
jawab sosialnya, sehingga membuat perusahaan swasta tidak menganggap bahwa tanggung jawab sosial perusahaan adalah kewajiban, melainkan sebuah kerelaan atau voluntary. Sebaiknya sanksi bagi perusahaan yang melanggar diatur secara tegas di UUPT.

3. Ketentuan tanggung jawab sosial perusahaan atau CSR bagi perusahaan swasta saat ini hanya menekankan kepada kewajiban melaksanakan tanggung jawab sosial perusahaan sebagaimana yang diatur dalam UUPT dan UUPM, namun tidak diaturnya ketentuan bagaimana suatu perusahaanmelaksanakan program CSR sehingga menyebabkan masing-masing perusahaan memiliki cara tersendiri untuk mengimplementasikan ketentuan CSR tersebut.

\section{PENUTUP}

\section{Kesimpulan}

Pengaturan CSR diatur dalam berbagai peraturan perundang-undangan, secara Internasional, ada ISO 26000 yang merupakan salah satu pedoman yang dapat digunakan oleh perusahaan dalam mengimplementasikan CSR dan bukanlah merupakan suatu sertifikasi. ISO 26000 menyediakan standar pedoman yang bersifat sukarela mengenai tanggung jawab sosial suatu institusi yang mencakup semua sektor, badan publik atau badan privat baik di Negara berkembang maupun Negara maju. Sedangkan secara nasional CSR telah diatur dalam beberapa peraturan perundang-undangan yaitu UUPT, UUPM, UUPLH, UU Minerba. UUPT mewajibkan perseroan yang bergerak dibidang dan/atau berkaitan dengan sumber daya alam wajib melaksanakan tanggung jawab sosial perusahaan. Sedangkan dalam UUPM disebutkan bawa setiap penanam modal berkewajiban untuk menerapkan prinsip tata kelola perusahaan yang baik, apabila tidak melaksanakannya dapat dikenakan sanksi administratif. Dalam UUPLH menyebutkan bahwa setiap orang yang melakukan usaha dan/atau kegiatan berkewajiban memberikan informasi yang terkait dengan perlindungan dan pengelolaan lingkungan hidup secara benar, akurat, terbuka, dan tepat waktu; menjaga keberlanjutan fungsi lingkungan hidup; dan menaati ketentuan tentang 
baku mutu lingkungan hidup dan/atau kriteria baku kerusakan lingkungan hidup. Dan pada UU Minerba, CSR diatur dalam pengaturan mengenai hak dan kewajiban pemegang IUP dan IUPK yaitu kewajiban untuk melaksanakan ketentuan keselamatan dan kesehatan kerja pertambangan, keselamatan operasi pertambangan, pengelolaan pemantauan lingkungan pertambangan termasuk kegiatan reklamasi dan pasca tambang, upaya konservasi mineral dan batubara, pengelolaan sisa tambang dari suatu kegiatan pertambangan dalam bentuk padat, cair atau gas sampai memenuhi standar baku mutu lingkungan sebelum dilepas ke media lingkungan

\section{Saran}

Pemerintah telah mengeluarkan beberapa kebijakan mengenai CSR, namun masih tersebar pada beberapa Peraturan perundang-undangan sehingga kurang mendalam pada pada pengaturannya, untuk itu pelaku bisnis atau perusahaan harus aktif dan kreatif dalam menentukan program CSRnya. Agar tercapainya tujuan untuk mewujudkan pembangunan ekonomi berkelanjutan guna meningkatkan kualitas kehidupan dan lingkungan yang bermanfaat bagi perusahaan, komunitas setempat dan masyarakat pada umumnya, maka Pemerintah Republik Indonesia sebaiknya membuat suatu pedoman pelaksana CSR yang diatur dalam satu peraturan perundang-undangan khusus mengatur mengenai CSR agar tercipta kejelasan hukum atas pelaksanaanya. 


\section{DAFTAR PUSTAKA}

\section{Buku}

Azheri, Busyra. Corporate Social Responsibility. Jakarta: PT. Rajawali Pers, 2011.

Budi, Hendrik. Corporate Social Responsibility. Jakarta: Sinar Grafika, 2008.

HS, Salim. Hukum Pertambangan Di Indonesia. Jakarta: PT. Rajawali Pers, 2010.

K. Bertens. Pengantar Etika Bisnis (Seri Filsafat Atmajaya: 21). Yogyakarta: Kanisius, 2002.

Manuel G. Velasquez. Business Ethics: Concepts and Cares (Fifth Edition). New Jersey: Pearson Education, Inc., 2002.

Philip Kotler, Nancy Lee.Corporate Social Responsibility: Doing the Most Good for Your Company and Your Cause. New Jersey: John Wiley and Sons, Inc., 2005.

Soekanto, Soerjono. Pengantar Penelitian Hukum, cet 3, Jakarta: UI Press, 2014.

Suharto, Edi. CSR \& Comdev Investasi Kreatif Perusahaan di Era Globalisasi. Bandung: Alfabeta, 2010.

Tjager, I Nyoman, et al. Corporate Governance (Tantangan dan Kesempatan bagi Komunitas Bisnis Indonesia). Jakarta: PT. Prehalindo, 2002.

Tunggal, Amin Widjaja. Corporate Social Responsibility. Jakarta: Rajawali, 2008.

Widjaja, Gunawan Widjaja, A. Yani. Seri Hukum Bisnis: Perseroan Terbatas. Jakarta: PT. Rajawali Pers, 2006.

\section{Peraturan Perundang-undangan}

Undang-Undang No. 40 Tahun 2007 tentang Perseroan Terbatas

Undang-Undang No. 25 Tahun 2007 tentang Penanaman Modal

Undang-Undang No. 32 Tahun 2009 tentang Perlindungan Dan Pengelolaan Lingkungan Hidup

Undang-Undang No. 22 Tahun 2001 Tentang Minyak Dan Gas Bumi

Undang-undang No. 32 tahun 2004 tentang Pemerintah Daerah 
Peraturan Pemerintah No. 47 Tahun 2012 tentang Tanggung Jawab Sosial Dan Lingkungan Perseroan Terbatas

Peraturan Menteri Negara Badan Usaha Milik Negara No. PER-05/MBU/2007 Tahun 2007 Tentang Program Kemitraan Badan Usaha Milik Negara Dengan Usaha Kecil

\section{Artikel}

Hardiansyah, HAM, CSR dan model sosial untuk membanguan sinergi bagi upaya pengentasan kemiskinan, makalah disampaikan pada seminar dan talkshow CSR pada tanggal 10 Agustus 2007.

Corporate Social Responsibility Community, Hambatan Dalam Penerapan CSR, http://info-csr.blogspot.co.id/2008/08/hambatan-dalam-penerapan-csr.html, diakses pada tanggal 18 Mei 2018.

Down to Earth, Pets Terhadap Dukungan Bank Dunia Untuk Tambang Nikel Baru, http://www.downtoearth-indonesia.org/id/story/petisi-terhadap-dukunganbank-dunia-untuk-tambang-nikel-baru, diakses pada tanggal 18 Mei 2018. 
92 ADIL: Jurnal Hukum Vol.10 No.2 